\title{
TARBAWI
}

Volume 3 No.1, Januari - Juni 2018

ISSN : 2527-4082

\section{Pembinaan Guru Pai Dalam Membiasakan Siswa Melaksanakan Shalat Berjamaah}

Teacher Training PAI In Familiarize Students Implement Prayers in congregation

Sitti Satriani. Is

Universitas Muhammadiyah Makassar

\begin{abstract}
Abstrak
Teknik yang digunakan dalam Jenis penelitian ini adalah penelitian deskriptif kualitatif. Penelitian deskriptif adalah penelitian yang bertujuan untuk menyelidiki dan menggambarkan keadaan, kondisi, Guru Pai Dalam Membiasakan Siswa Melaksanakan Shalat Berjamaah. Kegiatan bimbingan sholat tersebut dilakukan setiap hari 30 menit sebelum memulai proses pembelajaran diawali dengan membaca surat-surat pendek, sampai murid tersebut mahir dengan bacaan solat serta beberapa hafalan surat-surat pendek. Selain itu untuk memotifasi upaya yang dilakukan guru agama dalam meningkatkan motivasi siswa dalam membiasakan sholat berjamaah adalah dengan membuat berapa stiker di setiap sudut sekolah tentang pentingnya melaksanakan sholat berjamaah.
\end{abstract}

Kata kunci: Guru Pai, Siswa dan Sholat Berjamaah 


\begin{abstract}
The technique used in this research type is descriptive qualitative research. Descriptive research is research that aims to investigate and describe the circumstances, conditions, Guru Pai Allowing Students Carry In Salah Berjamaah. Activity guidance prayer is done every day 30 minutes before starting the learning process begins with reading letters pende $k$, until the student is proficient with reading solat and some memorized short letters. In addition to motivate efforts made religious teachers in improving students' motivation in getting used to praying together is to make how many stickers in every corner of the school about the importance of performing congregational prayers .
\end{abstract}

Keywords: Teacher PAI, Students and Sholat Berjamaah

\section{PENDAHULUAN}

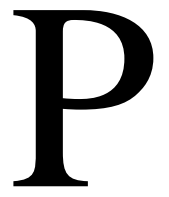

endidikan agama Islam mempunyai peranan penting dalam pembangunan suatu bangsa, karena keberhasilan suatu bangsa ditentukan oleh faktor manusianya, dalam hal ini pendidikan pada dasarnya merupakan suatu proses perubahan perilaku, melalui usaha perubahan sikap, watak, serta melatih diri dalam keterampilan yang bermanfaat.

Di sekolah guru hadir untuk mengabdikan diri pada umat manusia dalam hal ini anak didik. Negara menuntut generasi yang memerlukan pembinaan dan bimbingan dari guru. Guru dengan sejumlah buku yang terselip di pinggang datang ke sekolah diwaktu pagi hingga petang sampai waktu mengajar dia hadir di sekolah untuk bersama-sama berlajar dengan sejumlah anak didik yang sudah menantinya untuk diberikan pelajaran. Anak didik ketika itu haus akan ilmu pengetahuan dan siap untuk menerimanya dari guru. Ketika itu guru sangat berarti sekali bagi anak didik. Kehadiran seorang guru di kelas merupakan kebahagiaan bagi mereka apalagi bila pigur guru itu disenangi oleh mereka.

Keberhasilan pendidikan
manusia ditentukan
pemahamannya akan sumber
pendidikan terhadap proses belajar
mengajar, sebagaimana dirasakan oleh
manusia secara keseluruhan, terlebih-
lebih anak didik (siswa) pada
khususnya, utamanya masalah
pendidikan agama Islam.


Guru adalah pendidik profesional, secara implisit ia telah merelakan dirinya menerima dan memikul sebagian tanggung jawab orang tua. Mereka tidak hanya menyerahkan anaknya ke sekolah tapi sekaligus pelimpahan sebagian tanggung jawab pendidikan anaknya kepada guru, hal ini pun menunjukkan bahwa peranan dan tanggung jawab guru tidaklah muda. dari uraian pegertian guru di atas maka penulis dapat simpulkan bahwa guru adalah orang yang bertanggung jawab untuk mencerdaskan kehidupan anak didik, baik dalam perkembangan jasmani atau rohaninya untuk mencapai kedewasaannya, karena tidak ada seorang guru pun yang mengharapkan anak didiknya menjadi sampah masyarakat. Untuk itulah guru dengan penuh dedikasi dan loyalitas berusaha membimbing dan membina anak didik agar dimasa mendatang menjadi orang yang berguna bagi agama, bangsa dan negara.

Mendidik anak menjadi manusia yang taat beragama Islam ini, pada hakikatnya adalah sangat sulit, apalagi hidup di era sekarang ini, era dimana anak-anak sampai orang tua cenderung untuk meniru budaya yang tidak lagi Islami.

Shalat merupakan salah satu ibadah yang wajib dilaksanakan oleh segenap kaum muslimin. Lain dengan perintah Allah SWT. yang lain, yang disampaikan kepada Muhammad SAW. melalui malaikat jibril, perintah shalat ini diberikan langsung oleh Allah SWT. Nabi Muhammad SAW. menerima perintah untuk shalat saat melaksanakan Mi"raj. Shalat harus dikerjakan baik sendirian maupun berjamaah. Shalat merupakan media mendekatkan diri kepada Allah SWT. dan sarana memohon apa yang dibutuhkan oleh manusia dengan mensyukuri semua kasih sayang Allah SWT.

Seorang pendidik yang bijaksana sudah barang tentu terus mengupayakan yang lebih efektif dan efisien dengan menerapkan dasardasar pendidikan yang berpengaruh terhadap anak secara mental dan moral, spritual, saintikal dan etos sosial anak, sehingga anak dapat mencapai kematangan yang sempurna, memiliki wawasan yang luas dan berkepribadian integral. Salah satu yang bisa membuat anak menjadi anak yang agamis, jujur, bertanggung jawab 
dan lain-lain yaitu sholat berjamaah, selain itu keutamaan sholat berjamaah sebagaimana sabda Nabi SAW:

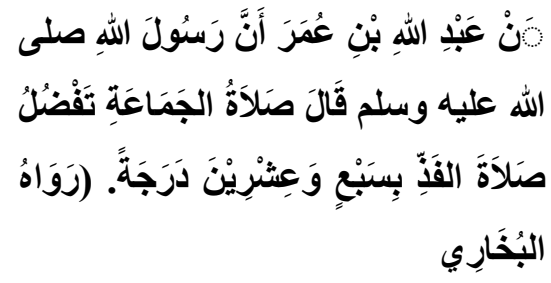

Artinya:

"Dari Abdullah bin Umar bahwasanya rasulullah saw bersabda Shalat berjamaah jama'ah itu lebih afdhal dari pada shalat berjamaah sendirian, dengan dua puluh tujuh derajat". (Abi Abdillah Muhammad bin Ismail bin Ibrahim bin Mughirah Bardazbah al Imam Bukhary al Ja'fi, Shahih Bukhari (1987 :318).

Di SDN No. 185 Impres Salambu Kecamatan Manggara bombang, Kabupaten Takalar, merupakan SD Negeri yang terbilang jauh dari kota kabupaten takalar, boleh dikata SDN Impres Salambu ini merupakan salah satu sekolah terpencil yang ada di kabupaten takalar, latar belakang orang tua sisiwa yang bersekolah di SDN tersebut adalah didominasi petani rumput laut dengan nelayan, mengingat sekolah tersebut memang terletak dipinggiran laut yang memiliki panorama alam yang sangat indah. jumlah siswa 106 orang, guru sebanyak 6 guru kelas dan 2 orang guru mata pelajaran, 1 orang penjaga sekolah. di SDN No 185 IMPRES Salambu ini belum sepenuhnya melaksanakan shalat berjamah, shalat berjamaah dilakukan hanya pada jam pelajaran agama, itupun ketika materi atau tema pembelajaran saat itu membahas tentang sholat, selain dari mesjid jauh dari sekolah, sekolah juga belum mendirikan musollah ataupun ruangan yang sementra digunakan sebagai musollah, sehingga pelaksanaan sholat berjamaah di SDN No. 185 Impres Salambu Kecamatan Manggara bombang, Kabupaten Takalar belum rutin di laksanakan, sementra kita ketahui bahwa Shalat jamaah yang dilaksanakan disekolah ini diterapkan juga dengan tujuan untuk membina karakter siswa, dapat meningkatkan sikap disiplin pada siswa, mengajarkan supaya mereka mau menjalankan shalat lima waktu di rumah terlebih dijalankan secara berjamaah di masjid lingkungan siswa tinggal. Di sekolah siswa dapat memanfaatkan waktu istirahatnya dengan baik dan melatih mereka untuk selalu membiasakan beribadah shalat 
tepat waktu. Kalau siswa sudah terbiasa shalat tepat waktu, insyaAllah kegiatan-kegiatan lain yang mereka kerjakan akan tepat waktu pula disiplin waktu, menghargai teman, mampu bermusyawarah, membiasakan sabar (dengan antri), berpakaian rapi dan hidup sederhana.

Selain bertujuan untuk melatih beribadah kepada siswa, diharapkan mereka juga menjadi lebih dekat atau akrab dengan sesama teman dan lebih menjaga sopan santun terhadap para guru, atau bahkan terhadap orang tua. Karena shalat yang dilaksanakan dengan bersama-sama dalam satu musollah, jadi secara tidak langsung mereka saling menjaga hubungan baik dengan sesama dan tidak saling mengganggu, serta lebih menjaga sopan santun terhadap para guru.

Dengan adanya shalat jamaah ini, suasana sekolah menjadi religius. Jadi, siswa tidak hanya menguasai teori-teori materi pelajaran saja, tetapi mereka diharapkan tidak melupakan ritual-ritual ibadah, salah satunya adalah shalat jamaah. Melalui kegiatan shalat berjamaah ini, diharapkan mampu meningkatkan kebiasaan siswa dalam mengaplikasikan dan menetapkan nilai-nilai ajaran agama
Islam yang diyakini menuju pembentukan manusia yang beriman dan bertakwa kepada Tuhan Yang Maha Esa secara utuh.

Dari Abu Hurairah, Rasululah shallallahu 'alaihi wa sallam bersabda;

"Barangsiapa bersuci di rumahnya lalu dia berjalan menuju salah satu dari rumah Allah (yaitu masjid) untuk menunaikan kewajiban yang telah Allah wajibkan, maka salah satu langkah kakinya akan menghapuskan dosa dan langkah kaki lainnya akan meninggikan derajatnya." (HR. Muslim no. 1553).

Shalat berjamaah adalah ibadah wajib yang harus dilakukang oleh semua umat islam tanpa terkecuali mulai dari beranjak dewasa sampai masuk ke dalam liang lahat (meninggal dunia). Bagi laki-laki shalat berjamaah di masjid juga merupakan kewajiban yang tidak bisa ditawar-tawar kecuali ada halangan yang serius. Sedangkan bagi perempuan justru sholat di rumah yang paling utama.

Manfaat, keuntungan, kelebihan serta kebaikan shalat berjama'ah di masjid tepat pada waktunya : 
a. Mendapatkan pahala/ kebaikan dari Allah Swt 27 derajat lebih tinggi daripada shalat berjamaah sendiri (Satu derajat jaraknya antara langit dengan bumi).

b. Shalat berjamaah malam di masjid pahalanya sangat besar sekali sehingga apabila manusia tahu maka mereka akan rela pergi ke masjid walaupun harusmerangkak/merayap.

c. Bisa berkomunikasi dan silaturahim dengan tetangga yang sesama muslim, bertanya tentang keadaan, dsb. Memberi senyum, jabat tangan dan salam saja sudah besar pahalanya.

d. Bisa shalat berjamaah di awal waktu sehingga kita tidak akan takut lupa shalat berjamaah atau kelewat, karena kebiasaan kita yang suka menunda-nunda waktu mengerjakan shalat berjamaah wajib subuh, zuhur, ashar, maghrib dan isya. Hidup kita akan jauh lebih tenang karena hidup lebih teratur/disiplin tidak perlu ingat-ingat sudah shalat berjamaah atau belum.

e. Kita bisa melatih kedisiplinan dan ketaatan kita kepada Allah SWT dengan rutin shalat berjamaah di masjid/mushola. Dengan menjadi pribadi yang disiplin dan takut atas azab Tuhannya maka hidup akan jauh menjadi berkualitas dan lebih baik dari orang lain yang tidak melakukannya.

f. Bagi para pemimpin, ia akan semakin dekat dengan yang dipimpinnya, karena bisa

g. Bertukar pikir (sharing) secara syah. (Fathul Bari 2005:133).

Guru pendidikan agama Islam juga belum menekankan sepenuhnya pentingnya sholat berjamaah terlebih ditekankan untuk siswa siswinya. Melihat realitas diatas maka tuliasan ini dimaksudkan untuk memberikan solusi bagaimana cara yang efektif dan efisien agar guru PAI mengupayakan membiasakan murid shalat berjama'ah, di SDN No. 185 Impres Salambu Kecamatan Manggara bombang, Kabupaten Takalar. 


\section{METODE PENELITIAN}

Adapun Teknik yang digunakan dalam Jenis penelitian ini adalah penelitian deskriptif kualitatif. Penelitian deskriptif adalah penelitian yang bertujuan untuk menyelidiki dan menggambarkan keadaan, kondisi, Guru Pai Dalam Membiasakan Siswa Melaksanakan Shalat Berjamaah. Secara aplikatif pelaksanaan metode penelitian deskriptif kualitatif tidak terbatas hanya sekedar pengumpulan dan penyusunan data, tetapi meliputi analisis dan interpretasi tentang arti data tersebut. Dalam penelitian deskriptif ini penulis berusaha mencatat, menganalisa, dan mngintrepretasikan kondisi yang ada. Adapun orientasi tulisan ini adalah mengkaji secara mendalam tentang Guru Pai Dalam Membiasakan Siswa Melaksanakan Shalat Berjamaah.

\section{PEMBAHASAN}

Dalam pelaksanaan program membiasakan siswa sholat berjamaah di SDN No. 185 Impres Salambu Kecamatan Manggarabombang, Kabupaten Takalar, banyak terdapat kegiatan didalamnya. Kegiatan IBM yang dikaukan di SDN Impres Salambu dimulai dengan Kegiatan guru PAI memberikan materi tentang keutamaan sholat berjamaah, Shalat berjamaah Materi yang ada adalah materi ibadah dimana siswa dibiasakan untuk shalat berjamaah tidak hanya di sekolah tetapi di luar lingkungan sekolah. Guru juga menekankan keutamaan shalat berjamaah. Untuk tingkat SD materi ibadah adalah mementingkan amal perbuatannya (praktek) serta ditambah dengan menerangkan mana yang perlu dan mana yang sunah di antara amal perbuatan.

Begitu juga diterangkan sesuatu yang membatalkan serta hikmah-hikmahnya untuk kehidupan perseorangan dan kebahagiaan masyarakat. Selain itu juga diterangkan tujuan amal ibadah yaitu untuk mengingat Allah dan mohon hidayah dan taufik kepada-Nya, supaya kita selamat dan berbahagia di dunia dan akhirat. Sebab itu segala bacaan dalam shalat harus muridmurid mengetahui arti dan maksudnya, sehingga shalat itu dikerjakan dengan jasmani dan rohani, bukan gerak-gerik saja seperti shalat anak-anak. Metode yang digunakan dalam kegiatan ini yaitu: 
1. Dengan pendahuluan misalnya guru menanyakan kepada murid bagaimana cara mengerjakan amal ibadah yang hendak diajarkannya.

2. Dengan bertanya jawab dengan siswa tentang bacaan-bacaan dan perbuatan dalam amal ibadah itu satu demi satu.

3. Menyebutkan ayat Al-Quran atau Hadis yang berhubungan dengan amal perbuatan yang benar, Kegiatan ini merupakan praktek kegiatan intra kurikuler. Karena terbatasnya waktu maka kemungkinan siswa untuk menguasai materi sanagat terbatas.

Kegiatan ini meliputi praktek ibadah dan melakukan latihan gerakan dan bacaan shalat. Shalat berjamah dapat diambil makna pengajaran manusia akan kepekaan sosial. Dimana dalam shalat berjamaah dilakukan bersamasama tidak mengutamakan antara yang satu dengan yang lainnya dari sisi derajat pangkat dan status sosial lainnya. Manusia dianggap sama, mereka belajar membuat shaf-shaf yang rapat dan lurus, melakukan gerakan yang sama, siapa yang dahulu datang berhak menempati shaf depan. Mereka bersama-sama melakukan munajat kepada Tuhan. Perasaan ini mampu melahirkan sikap sebagai satu badan atau tubuh. Apabila ada salah satu bagian tubuh yang sakit, menjadi tanggung jawab semua, sehingga seringnya seseorang melakukan shalat berjamaah memudahkan jalur berkomunikasi antar sesama. Akhirnya rasa kemanusiaan dalam pribadi masing-masing yang wujudnya berupa perasaan ingin membantu memecahkan problem yang dihadapi seeorang, karena ia adalah bagian dari tubuh yang satu. Kewajiban shalat lima waktu dalam sehari-semalam, terus menerus dikerjakan dengan sempurna (memenuhi rukun dan syaratnya) dapat menentramkan jiwa, lebih mendekatkan diri pada Allah, tetapi shalat harus dilakukan dengan khusyu' dan menghadirkan hati pada Allah. Shalat yang dilakukan secara kontinyu, tekun, dan penuh kesadaran akan menjadi alat pendidikan jasmani dan rohani yang efektif, dapat memelihara jiwa serta memupuk pertumbuhan kesadaran. Makin banyak shalat dilakukan dengan kesadaran bukan dengan paksaan dan 
tekanan, berarti sebanyak itu rohani dan jasmani dilatih berhadapan dengan Allah.

Kegiatan bimbingan sholat tersebut dilakukan setiap hari 30 menit sebelum memulai proses pembelajaran diawali dengan membaca surat-surat pendendek, sampai murid tersebut mahir dengan bacaan solat serta beberapa hafalan surat-surat pendek. Selain itu untuk memotifasi upaya yang dilakukan guru agama dalam meningkatkan motivasi siswa dalam membiasakan sholat berjamaah adalah dengan membuat berapa stiker di setiap sudut sekolah tentang pentingnya melaksanakan sholat berjamaah.

Selain itu juga upaya yang dilakukan guru terutama guru pendidikan agama islam dalam membiasakan solat berjamaah adalah dengan :

1. Keteladanan dalam pendidikan merupakan metode yang paling berpengaruh dan terbukti paling berhasil dalam mempersiapkan dan membentuk aspek moral, spiritual, dan etos sosial anak didik. Mengingat pendidik adalah seorang figur terbaik dalam pandangan anak didik, yang kepribadian dan sopan santunnya, disadari atau tidak akan ditiru oleh anak didik. Seringnya guru mencontohkan kepada siswa tentang shalat berjamaah di lakukan dilingkungan sekolah ataupun dimesjid terdekat seolah menjadikan anak selalu atau rutin melaksanakan shalat berjamaah, selanjutnya jika hal tersebut kadang-kadang di contohkan oleh guru maka siswa tersebut kadangkadang pula melaksanakan shalat berjamaah, malah anak tidak akan pernah mendirikan shalat berjamaah jika guru sendiri tidak pernah melaksanakan shalat berjamaah. Maka keteladaan disini merupakan hal yang mutlak di lakukan oleh seorang guru agama.

2. Melalui Pembiasaan, Pembiasaan adalah upaya praktis dalam pendidikan dan pembinaan anak. Hasil dari pembiasaan yang dilakukan seorang pendidik adalah terciptanya suatu kebiasaan bagi anak didiknya. "Kebiasaan itu adalah suatu tingkah laku tertentu yang sifatnya otomatis, tanpa direncanakan dulu, serta berlaku begitu saja tanpa dipikir lagi” ( Edi Suardi, tt. : 123 ). Seorang anak 
yang terbiasa mengamalkan nilainilai ajaran Islam lebih dapat diharapkan dalam kehidupannya nanti akan menjadi seorang Muslim yang saleh. Pembiasaan ini jika dilakukan terus menerus maka akan menjadi karakter dan ketika karakter menjadi anak yang cinta akan sholat berjaah maka akan menjadi kebutuhan, dan dipastikan ketika solah sudah menjadi kebutuhan otomatis tampa dorongan atau perintah dari siapa pun maka yakin setian siswa akan dengan sendirinya melaksanakan sholat berjamaah. Dan hal ini tentunya salah satu jalan yang sangat tepat yang dilakukan oleh guru Pai dalam membiasakan siswanya sholat berjamaah di SDN No. 185 Impres Salambu Kecamatan Manggarabombang, Kabupaten Takalar,

3. Pemberian Nasehat, Metode pendidikan semacam ini cukup berhasil dalam pembentukan akidah siswa dan mempersiapkan baik secara moral, emosional, maupun sosial yang merupakan pendidikan anak dengan petuah memilki pengaruh yang cukup besar dalam membuka mata kesadaran anak-anak. dengan demikian, para pendidik hendaknya memahami betul akan hakikat ini dan menggunakan metode-metode Al-Qur`an dalam upaya memberikan nasehat, peringatan, dan bimbingan untuk mempersiapkan generasi muda yang tangguh, berwacana Islami dan pengetahuan yang handal. Pemberian nasehat ini dilakukan terus menerus baik di dlam kelas maupun dilingkungan sekolah atau pun di luar lingkungan sekolah dimana siswa berada, pemberian nasehat ini juga guru Pai mengingatkan kepada kedua orang tua siswa untuk senantiasa memberikan nasehat dan mengingatkan kepada anaknya tentang hal kebaikan terlebih masalah ibadah sholat dan mengutamakan sholat berjamaah di rumah.

Pendidikan dengan memberi Perhatian/ Pengawasan. Adapun yang dimaksud dengan perhatian adalah senantiasa mencurahkan perhatian penuh dan mengikuti perkembangan aspek aqidah dan moral anak, mengawasi dan memperhatikan kesiapn mental dan sosial, disamping 
selalu bertanya tentang situasi pendidikan jasmani dan kemampuan ilmiahnya. Islam, dengan keuniversaliannya prinsipnya dan peraturannya yang abadi, memerintah para bapak, ibu, dan pendidik untuk memperhatikan dan senantiasa mengikuti serta mengawasi anakanaknya dalam segala segi kehidupan dan pendidikan yang universal. Sebagaimana dalam surat At-Tahrim : 6, menguraikan suatu keharusan pengawasan ruang lingkup keluarga. Ali r.a mengartikan qu anfusakum dengan "didiklah dan ajarilah" sedangkan umar r.a menafsirkan "melarang mereka dari apa yang dilarang Allah".

perhatian dan pengawasan ini merupakan fondasi dalam membentuk karakter anak baik perhatian dan pengawasan yang dilakukan oleh orang tua maupun guru, kecendrungan anak dimasa moderen saat ini banyak menjerumuskan dirinya dengan hal negatif diakibatkan kurangnya perhatian dan pengawasan oleh sebab itu dalam IBM ini sangat ditekankan perhatian dan pengawasan ini betulbetul dimiiki oleh setiap orang tua dan guru khususnya guru PAI, dan salah satu cara agar perhatian dan pengawasan ini tercapai dengan baik serta tujuan yng ingin dicapai terwujud dengan memberikan perhatian dan pengawasan tentang sholat yang dilakukan oleh siswa, insya allah dengan siswa terjaga solatnya baik dirumah maupun disekoah insya allah siswa akan menemukan tujuan hidup yang lebih baik, begitupula orang tua dengan memberikan perhatian kepada anak salah satunya dengan mengajak mereka solat berjamaah selain dari kewajiban adadalah salah satu bentuk perhatian dan secara tidak langsung ada pengawasan batin didalam tercipta untuk anak itu sendiri.

Karena ruangan kelas di SDN No. 185 Impres Salambu Kecamatan Manggarabombang, Kabupaten Takalar, belum banyak dan musollah belum ada, maka alternatif kepala sekolah di Di SDN No. 185 Impres Salambu Kecamatan Manggara bombang, Kabupaten Takalar, untuk efektifnya sholat berjamaah maka pelaksanaan sholat berjamaah dilaksanakan di perpustakaan, jadi untuk sementra perpustakaan sekolah berfungsi ganda selama proses belajar mengajar berlangsung perpustakaan berfungsi sebagai ruang baca, pada 
saat waktu sholat tiba maka perpustakaan tersebut berubah menjadi tempat pelaksanaan sholat berjamaah. Pada IBM ini sudah membuat tempat berwudhu meskipun masi jauh dr kesempurnaan, mengingat dana belum mencukupi untuk membuat tempat mengambil wudhu yang lebih baik, jadi inisiatif IBM membuat serta para guru di SDN No. 185 Impres Salambu Kecamatan Manggarabombang, Kabupaten Takalar,dengan membuat tempat wudhu di dekat WC dengan membuat sebanyak empat mata kerang air, diiberi pemisah antara tempat wudhu pria 2 buah kerang air dan untuk putri dua kerang mata air.setidaknya ini mengurangi antrian siswa mengambil air wudhu.

\section{PENUTUP}

Kegiatan bimbingan sholat tersebut dilakukan setiap hari 30 menit sebelum memulai proses pembelajaran diawali dengan membaca surat-surat pendendek, sampai murid tersebut mahir dengan bacaan solat serta beberapa hafalan surat-surat pendek. Selain itu untuk memotifasi upaya yang dilakukan guru agama dalam meningkatkan motivasi siswa dalam membiasakan sholat berjamaah adalah dengan membuat berapa stiker di setiap sudut sekolah tentang pentingnya melaksanakan sholat berjamaah.

Selain itu juga upaya yang dilakukan guru terutama guru pendidikan agama islam dalam membiasakan solat berjamaah adalah dengan :

1. Keteladanan

2. Melalui Pembiasaan,

3. Pemberian Nasehat,

\section{DAFTAR PUSTAKA}

Ahmadi Abu, Metodik Khusus Pendidikan Agama (MKPA), Bandung: CV. Armico, 1986.

Al-Hamd Ibrahim bin Muhammad, Bersama Pendidik Islam, Jakarta: Darul Haq, 2002.

Ali Muhammad, Guru Dalam Proses Belajar Mengajar, Cet. XI; Bandung: Sinar Baru, Algensindo, 2002

Daradjat Zakiah, Ilmu Pendidikan Islam, (Cet. II; Jakarta: Bumi Aksara, 1992).

Sardiman, Interaksi dan Motivasi Belajar Mengajar Bagi Guru dan Calon Guru, Cet. VI; Jakarta:PT. Ikrar Mandiriabadi, 1996.

Surabaya IKIP Kurikulum Metodik Didaktik Team, Pengantar Didaktik Metodik Kurikulum 
PBM, Cet. IV; Jakarta: CV. Rajawali, 1989.

Slameto, Belajar dan Faktor-Faktor yang Mempengaruhinya, Cet. III; Jakarta: PT. Rineka Cipta, 1995.

Ulwan Nashih, Pendidikan Anak Dalam Islam, Cet. II; Jakarta: Pustaka Amani, 1999.

Zuhairini, Ghofir Abdul, Yusuf Slamet As, Metodik Khusus
Pendidikan Agama

Dilengkapi Dengan system Modul dan Permainan Simulasi, Surabaya: Usaha Nasional, 1981.

Zuhairini, Ghofir Abdul, Yusuf Slamet As, Metodik Khusus Pendidikan Agama Dilengkapi Dengan system Modul dan Permainan Simulasi, Surabaya: Usaha Nasional, 1981. 